\title{
Latest Miocene restriction of the Mediterranean Outflow Water: a perspective from the Gulf of Cádiz
}

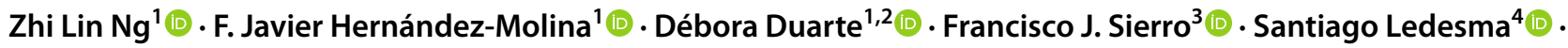

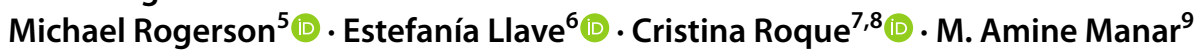

Received: 22 September 2020 / Accepted: 14 April 2021 / Published online: 17 May 2021

(C) The Author(s) 2021, corrected publication 2021

\begin{abstract}
The Mediterranean-Atlantic water mass exchange provides the ideal setting for deciphering the role of gateway evolution in ocean circulation. However, the dynamics of Mediterranean Outflow Water (MOW) during the closure of the Late Miocene Mediterranean-Atlantic gateways are poorly understood. Here, we define the sedimentary evolution of Neogene basins from the Gulf of Cádiz to the West Iberian margin to investigate MOW circulation during the latest Miocene. Seismic interpretation highlights a middle to upper Messinian seismic unit of transparent facies, whose base predates the onset of the Messinian salinity crisis (MSC). Its facies and distribution imply a predominantly hemipelagic environment along the Atlantic margins, suggesting an absence or intermittence of MOW preceding evaporite precipitation in the Mediterranean, simultaneous to progressive gateway restriction. The removal of MOW from the Mediterranean-Atlantic water mass exchange reorganized the Atlantic water masses and is correlated to a severe weakening of the Atlantic Meridional Overturning Circulation (AMOC) and a period of further cooling in the North Atlantic during the latest Miocene.
\end{abstract}

\section{Introduction}

Zhi Lin Ng

Zhi.Ng.2016@live.rhul.ac.uk

1 Department of Earth Sciences, Royal Holloway, University of London, Egham TW20 0EX, UK

2 Instituto Português do Mar e da Atmosfera (IPMA), 1749-077 Lisboa, Portugal

3 Departamento de Geología, Universidad de Salamanca, 37008 Salamanca, Spain

4 Naturgy Energy Group S.A., 28033 Madrid, Spain

5 Department of Geography and Environmental Sciences, Northumbria University, NE1 8ST Newcastle upon Tyne, UK

6 Instituto Geológico y Minero de España (IGME), 28003 Madrid, Spain

7 Estrutura de Missão para a Extensão da Plataforma Continental (EMEPC), 2770-047 Paço de Arcos, Portugal

8 Instituto Dom Luiz (IDL), Faculdade de Ciência da Universidade de Lisboa, 1749-016 Lisboa, Portugal

9 Office National des Hydrocarbures et des Mines (ONHYM), B.P. 99 Rabat, Morocco
Gateway evolution plays a significant role in the reorganization of global ocean circulation (Berggren 1982; Knutz 2008; Straume et al. 2020). The Mediterranean-Atlantic water mass exchange provides the ideal setting for such research. At present, the Mediterranean-Atlantic exchange is characterized by an anti-estuarine circulation (Wüst 1961) involving a surficial Atlantic inflow and a deeper outflow, known as the Mediterranean Outflow Water (MOW), through the Strait of Gibraltar (Sánchez-Leal et al. 2017). The MOW is predominantly sourced from the intermediate water mass of the Mediterranean, known as the Levantine Intermediate Water (LIW) (Millot et al. 2006). Upon exiting the Strait of Gibraltar, the dense MOW cascades onto the Gulf of Cádiz continental slope, entraining or mixing with Atlantic ambient water to form the Atlantic Mediterranean Water (AMW) (Rogerson et al. 2012b). The entrained ambient water is mainly sourced from the Azores Current, which originates at the Azores Front, the boundary between the European and African surface water masses (Rogerson et al. 2004). The resulting AMW water mass settles along the middle continental slope $(\sim 1000-1500 \mathrm{~m})$ and flows northwards above the North Atlantic Deep Water (NADW) (O’Neill-Baringer and Price 1997; Hernandez-Molina et al. 
2016). MOW input into the Atlantic has a significant impact on the formation of the NADW and on the thermohaline circulation (Pérez-Asensio et al. 2012), known as the Atlantic Meridional Overturning Circulation (AMOC). Removal or interruption of MOW would significantly impact the AMOC by $\sim 15 \%$ and reduce sea surface temperatures by up to $1{ }^{\circ} \mathrm{C}$ (Rogerson et al. 2012b). The AMOC plays a vital role in the earth's climate through the northward transport of heat and $\mathrm{CO}_{2}$, which bears an impact on the Arctic sea ice volume (Liu et al. 2020) and the ocean-terrestrial carbon cycle (Zickfeld et al. 2008).

The Mediterranean-Atlantic exchange was also active through the Late Miocene gateways (Fig. 1; 11.6-6.9 Ma; Krijgsman et al. 2018), which include the Betic and Riffian Corridors currently exposed onshore southern Spain and northern Morocco, respectively (Capella et al. 2017), and possibly the Strait of Gibraltar (Krijgsman et al. 2018). It is thought to have ceased or become reduced during the latest Miocene, causing the isolation of the Mediterranean
Sea from the Atlantic Ocean, hence the Messinian salinity crisis (MSC; 5.97-5.33 Ma; Krijgsman et al. 1999; Manzi et al. 2018). However, since formulating the MSC concept, Selli (1960) also argued for the early Messinian $(\sim 7.25 \mathrm{Ma})$ as the actual beginning of the MSC; it is marked by dystrophic faunal elements in the Mediterranean as the earliest indication of an ongoing restriction of the exchange. Yet restriction of MOW from the Mediterranean-Atlantic water mass exchange is one of the prerequisites for hypersaline conditions to deposit MSC evaporites (Flecker et al. 2015). In the Mediterranean, an inferred base-level fall and erosion of its margins during the MSC acme, and subsequent refilling by an open marine connection with the Atlantic, respectively resulted in a regional Messinian erosional surface (MES; 5.61 Ma) and a sharp lithological and paleontological change across the Miocene-Pliocene boundary (5.33 Ma) (Roveri et al. 2014). In turn, the onset of the MSC (5.97 Ma) shows no correlation to glacio-eustatic change and was thought to

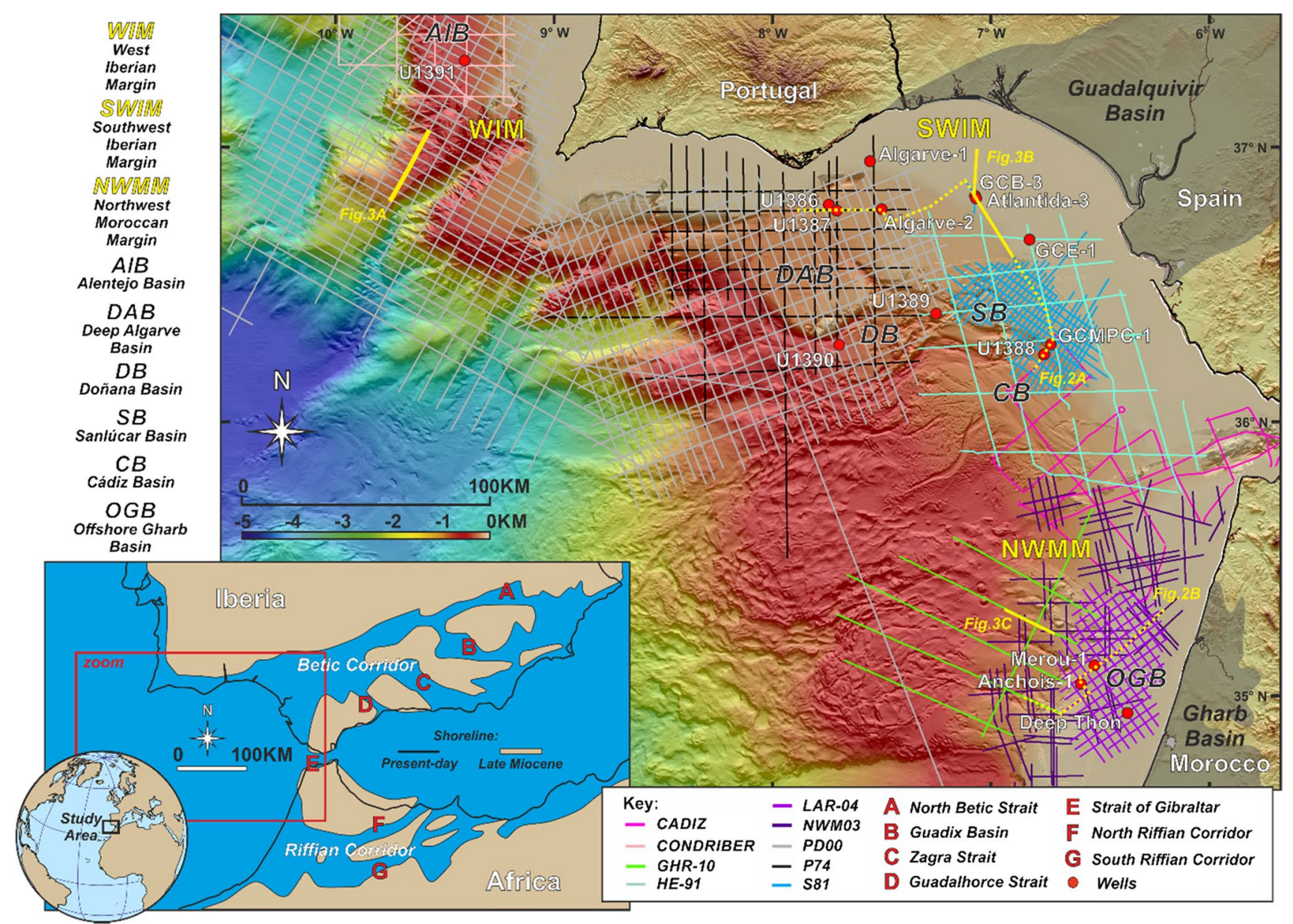

Fig. 1 Dataset including post-stack, time-migrated multichannel twodimensional (2D) seismic reflection surveys from ONHYM, Repsol S.A. and TGS-Nopec; borehole data from exploration wells and
IODP Expedition 339 scientific sites. Coordinate system: WGS 84 UTM 29 N. (Inset) Geographic location of the Gulf of Cádiz and the Late Miocene and present-day gateways 
be controlled dominantly by tectonics (Flecker and Ellam 2006; Hodell et al. 2001; Krijgsman et al. 2004).

In the Atlantic domain, open marine conditions have prevailed throughout the Miocene to the present (Flecker et al. 2015). Locally, the continental margins surrounding the Gulf of Cádiz were affected by gravitational processes due to rapid regional uplift and tectonic instability after the Middle to Late Miocene Betic-Rif Orogeny (Duggen et al. 2003). The Betif-Rif Orogery, due to convergence between Africa and Eurasia, transformed a wider Middle Miocene gateway ( $\sim 15 \mathrm{Ma}$ ) into several Late Miocene narrow and shallow corridors $(\sim 8 \mathrm{Ma})$ affecting MOW distribution, namely the North Betic Strait, Guadix Basin, Zagra Strait, Guadalhorce Strait and the North and South Riffian Corridors (Fig. 1; Capella et al. 2019; Krijgsman et al. 2018). The continuous constriction and closure of these corridors and the reduction of the water mass exchange are collectively known as the Mediterranean-Atlantic gateway restriction (Krijgsman et al. 2018; Pérez-Asensio et al. 2012). The distribution of contourite depositional systems within these corridors serves as evidence of bottom current influence from the MOW as it exits the Mediterranean (de Weger et al. 2020; Martín et al. 2009). The increase in bottom current velocities as a consequence of the ongoing restriction of the corridors, and the initiation of an overflow setting for the MOW across the MediterraneanAtlantic water mass exchange, resulted in the deposition of sandy contourites in the Betic and Riffian Corridors during the late Tortonian to early Messinian (7.8-7.25 Ma; Capella et al. 2017; de Weger et al. 2020; Martín et al. 2009) but has yet to be described for the Gulf of Cádiz. During this period, the Gulf of Cádiz would have represented the downstream continuation of the Betic and Riffian Corridors for MOW circulation after exiting the Mediterranean. Relocation of the contourite depositional system to the Gulf of Cádiz, within the Deep Algarve, Doñana, Sanlúcar and Cádiz basins (Fig. 1), occurred from Pliocene to the present (5.33 Ma onwards), with the MOW flowing through the Strait of Gibraltar (Hernández-Molina et al. 2014, 2016). However, the Strait of Gibraltar might have opened earlier in the early Messinian (Krijgsman et al. 2018). Meanwhile, the Guadalquivir and Onshore Gharb basins (Fig. 1), located at the western end of the Betic and Riffian Corridors, became marine embayments after the closure of these corridors (Capella et al. 2017; Pérez-Asensio et al. 2012). Despite extensive outcrop studies carried out onshore, the timing of the final closure of the gateways remains unknown, due to erosional hiatuses in the sedimentary record (Capella et al. 2017; Hüsing et al. 2010). Some outcrop studies suggest that the closure of the gateways occurred well before the onset of the MSC (Kouwenhoven et al. 1999; Martin et al. 2002), whereas modeling studies suggest that a narrow $(\sim 1 \mathrm{~km})$ and shallow $(\sim 10 \mathrm{~m})$ connection is sufficient to supply the salt for the MSC evaporites (Meijer and Krijgsman 2005).

Here, we define the middle to late Messinian sedimentary evolution and its relationship with its upper and lower bounding stratigraphic units in the Neogene basins (Offshore Gharb, Deep Algarve, Doñana, Sanlúcar, Cádiz and Alentejo basins), located on the upper to middle continental slope of the Northwest Moroccan (NWMM), the Southwest Iberian (SWIM) and the southern part of the West Iberian (WIM) margins (Fig. 1) using seismic stratigraphic analysis, correlated to chronology and lithology from borehole data (Fig. 2). We compared the distribution of the middle to upper Messinian succession with the Guadalquivir and Onshore Gharb basins (Fig. 1), based on the literature, to evaluate its significance for the Mediterranean-Atlantic water mass exchange and its implications for sedimentary and paleoceanographic processes in the Atlantic. For the first time, we investigated the paleoceanographic scenarios for the Late Miocene Mediterranean-Atlantic water mass exchange through a hypothetico-deductive method, using a simple quantitative representation of the system together with seismo-stratigraphic evidence and observations.

\section{Materials and methods}

\section{Seismic analysis and borehole correlation}

We compiled a regional database of seismic reflection and borehole data in the Gulf of Cádiz to the southern part of the West Iberian margin (Fig. 1). We carried out seismic interpretation of the database, which entailed the identification of seismic facies and boundaries, focusing on the middle to late Messinian unit. We utilized the nomenclature for seismic facies description and interpretation of Prather et al. (1998) based analogously on an intraslope basin setting in the Gulf of Mexico, which characterized three primary seismic facies categories (chaotic, convergent and draping). The seismic stratigraphy was correlated to borehole data (Fig. 2) consisting of lithological and chronological information (Table S1). They include five wells available from the literature: Algarve-2 (Hernández-Molina et al. 2016), Atlantida-3 and Golfo de Cádiz B-3 (GCB-3; Ledesma 2000), Golfo de Cádiz Mar Profundo C-1 (GCMPC-1; Hernández-Molina et al. 2014) and U1387 (van der Schee et al. 2016); three additional wells: Anchois-1, Deep Thon-1 and Merou-1, were acquired from an internal report for petroleum exploration by Repsol S.A., titled "Tanger-Larache Sedimentological study" (hereinafter referred to as Repsol S.A. 2013). The chronological information is based on bio- and cyclo-stratigraphic dating acquired from boreholes with top-only penetration of the middle to late Messinian unit in U1387 (van der Schee et al. 2016) and Algarve-2 (Hernández-Molina 


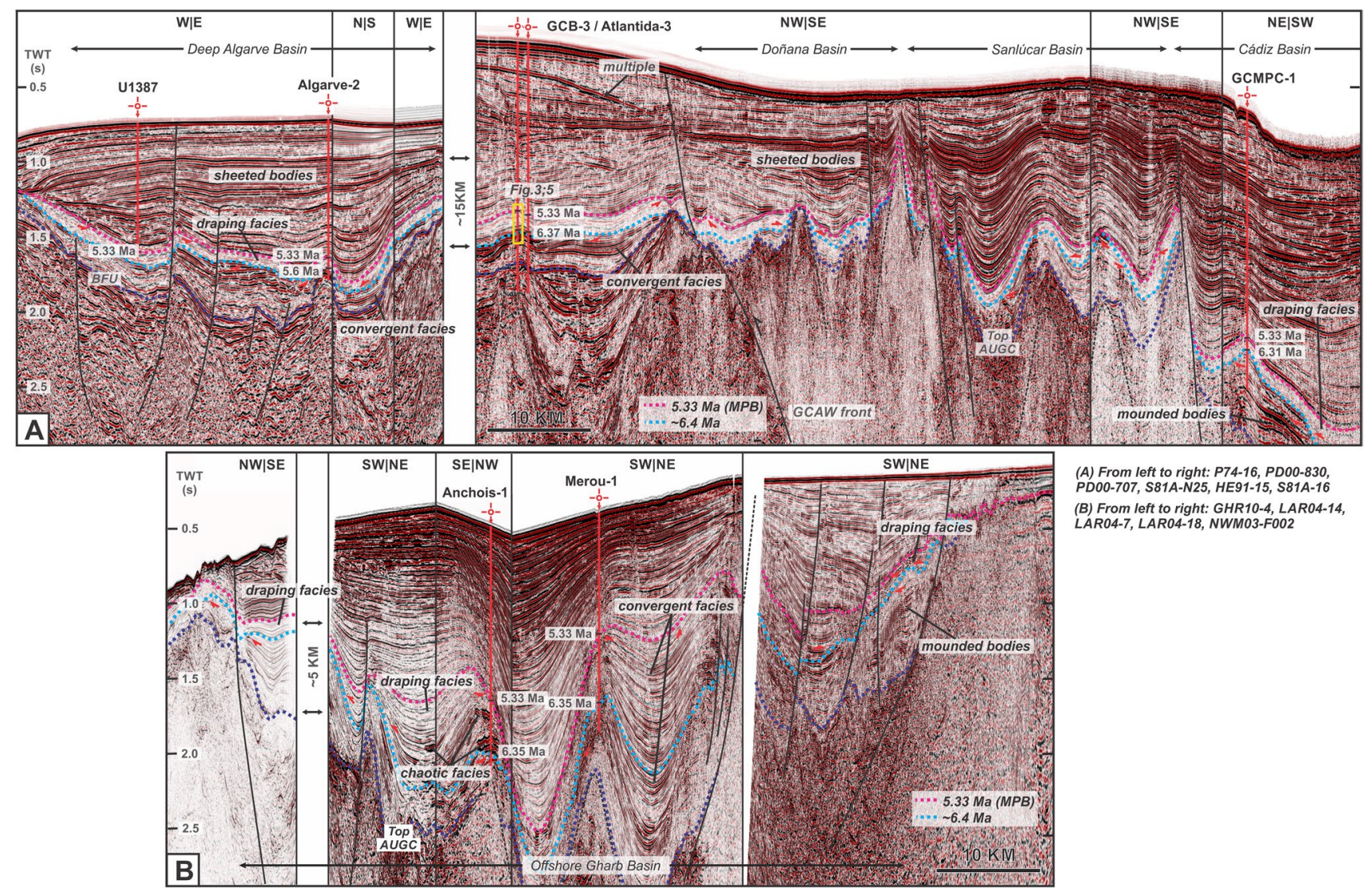

Fig. 2 Seismostratigraphy and regional distribution of the middleupper Messinian unit in a Southwest Iberian (SWIM) and b Northwest Moroccan margins regional profile (uninterpreted seismic profile in Fig. S2 - supplementary material) with borehole correlations to

et al. 2016), while its base is reached in Atlantida-3 and GCB- 3 (Ledesma 2000), GCMPC-1 (Hernández-Molina et al. 2014), Anchois-1, Deep Thon-1 and Merou-1 (Repsol S.A. 2013) (Table S1).

\section{Quantitative exploration of past flow conditions}

We adopted simple quantitative representations below to test three possible scenarios through a hypothetico-deductive method, based on the climatic, paleogeographic and paleoceanographic conditions during the middle to late Messinian, where a two-way water mass exchange between the Atlantic and the Mediterranean could be active. These experiments directly test hypotheses drawn from seismic and borehole analysis, which is limited to determining the presence or absence of flow on the slope, and the bottom velocity thresholds required for muddy and sandy bedform deposition. Key to the latter is the threshold at which sandy contourite deposition commences, as we expect deposits of this nature to be resolved in seismic data as packages with variable impedence. Field and experimental works (e.g. Culp et al. 2020; McCave et al. 2017; McCave and Hall 2006) indicate
U1387 (van der Schee et al. 2016), Algarve-2 (Hernández-Molina et al. 2016), Atlantida-3 and GCB-3 (Ledesma 2000) and GCMPC-1 (Hernández-Molina et al. 2014) (Table S1 in supplementary material)

that winnowing of muddy marine sediments and construction of muddy bedforms occurs at flow velocities higher than $0.15 \mathrm{~m} \mathrm{~s}^{-1}$, while winnowing, reworking and accumulation of sandy marine sediments occur at flow velocities higher than $0.2 \mathrm{~m} \mathrm{~s}^{-1}$. Consequently, the maximum MOW or AMW plume velocity on the Gulf of Cádiz upper to middle slope for the middle to late Messinian, where no contourite deposition is observed within the seismic resolution of our dataset, would be $0.2 \mathrm{~m} \mathrm{~s}^{-1}$, while the physical oceanography of the exchange must be consistent with generating flow no faster than this value. We also investigated a MOW or AMW plume velocity of $0.15 \mathrm{~m} \mathrm{~s}^{-1}$ for the threshold of silt-rich muddy contourite formation by bottom currents. Three scenarios allowing for a continuing MOW are explored here:

- Scenario A: The flux of exchange (and thus the size of the plume) was so small that the area impacted on the slope could not be resolved by the seismic analysis;

- Scenario B: The flow was slower during the middle to late Messinian than it was during the late Tortonian to early Messinian, where contourite deposition can be observed; and 
- Scenario C: The seismic analysis does not cover the region over which the MOW or AMW was flowing during the middle to late Messinian.

Following previous intensive research into these relationships (Rogerson et al. 2012a; Simon and Meijer 2015), we used Eqs. (1)-(6) to represent the system,

$\frac{Q_{\mathrm{MOW}}}{Q_{\text {inflow }}}=1 /\left(\frac{S_{\mathrm{M}}}{S_{\mathrm{A}}}\right)$

$Q_{\mathrm{AMw}}=Q_{\mathrm{MOW}} / \phi$

$\phi=1-\frac{B_{\text {geo }}^{1 / 3}}{U_{\text {geo }}}$

$B_{\text {geo }}=\frac{H_{\mathrm{MOW}} U_{\mathrm{MOW}} \mathrm{g}^{\prime}}{\left(1+2 K_{\mathrm{geo}} \mathrm{x} / w_{\mathrm{MOW}}\right)}$

$U_{\text {geo }}=\mathrm{g}^{\prime} \alpha / f$

$\mathrm{g}^{\prime}=\frac{\rho_{\mathrm{AMW}}-\rho_{\mathrm{ATL}}}{\rho_{\mathrm{AMW}}}$

where $Q_{\text {inflow }}, Q_{\mathrm{AMW}}$ and $Q_{\mathrm{MOW}}(\mathrm{Sv})$ are respectively the fluxes of Atlantic inflow, AMW and MOW; $S_{\mathrm{M}}$ and $S_{\mathrm{A}}$ (PSU) are the salinities of the Mediterranean and Atlantic water, respectively; $\phi$ is the mixing coefficient of AMW and MOW; $B_{\text {geo }}$ and $U_{\text {geo }}\left(\mathrm{m} \mathrm{s}^{-1}\right)$ are geostrophic buoyancy flux and velocity, where $B_{\text {geo }}$ is measured by $H_{\text {MOW }}(\mathrm{m}), U_{\text {MOw }}(\mathrm{m}$ $\mathrm{s}^{-1}$ ) and $w_{\text {MOW }}(\mathrm{m})$, which are the height, velocity and width of pure MOW at the gateway, $K_{\text {geo }}\left(\mathrm{m} \mathrm{s}^{-1}\right)$, which is the geostrophic Ekman number (assumed 0.2) and $\mathrm{x}(\mathrm{m})$, which is the distance downslope from which mixing or entrainment occurs (assumed $100,000 \mathrm{~m}$, while $U_{\text {geo }}$ is measured by g', which is the density anomaly of the plume within the ambient water, $\alpha$, which is the slope the water is moving over and $f$, which is the acceleration due to Coriolis force (assumed $0.000084 \mathrm{~m} \mathrm{~s}^{-2}$ ); g' is determined from $\rho_{\mathrm{AMW}}$ and $\rho_{\text {ATL }}\left(\mathrm{kg} \mathrm{m}^{-3}\right)$, which are respectively the densities of AMW and ambient Atlantic water (Rogerson et al. 2012b).

Today, the velocity of water $\left(U_{\text {geo }}\right)$ interacting with bedform-dominated sediment surfaces varies between $1.4 \mathrm{~m} \mathrm{~s}^{-1}$ for regions with sandy contourites or abrasion surfaces and $0.3-0.5 \mathrm{~m} \mathrm{~s}^{-1}$ for muddy contourites (O'Neill-Baringer and Price 1999). The higher velocities in proximal parts of the system reflect the presence of an unmixed core of MOW water which is yet to frictionally entrain ambient Atlantic water and thus relates directly to the modern salinity difference of the Mediterranean and Atlantic water of $\sim 2$ PSU
(Rogerson et al. 2012b). The lower velocities in the distal part of the system reflect water almost completely mixed to produce AMW (Atlantic Mediterranean Water) composition and thus relates to the density of the plume of water that lies at neutral density in the Atlantic.

\section{Results}

\section{Seismic analysis}

Seismic interpretation of the Gulf of Cádiz continental slope shows three main sedimentary intervals above a basin-wide erosional unconformity known as the basal foredeep unconformity (BFU; 8.2 Ma, sensu Maldonado et al. 1999). The BFU is juxtaposed against a thick chaotic body pinching out northwards, known as the Allochthonous Unit of the Gulf of Cádiz (AUGC; Fig. 2; sensu Medialdea et al. 2004). Above the BFU, an upper Tortonian-lower Messinian ( 8.2 to $\sim 6.4 \mathrm{Ma}$ ) succession consisting of high-amplitude convergent-by-baselap facies (Fig. 3b) is observed along the Southwest Iberian margin. In the Northwest Moroccan margin and the southern part of the West Iberian margin, the upper Tortonian-lower Messinian succession consists of cyclical alternations of low-to-high-amplitude reflections in sheeted or mounded geometries adjacent to basin margins (Fig. 3a and c). The top of the upper Tortonian-lower Messinian succession is bounded by, or locally truncated against, an unconformity.

Overlying the upper Tortonian-lower Messinian succession is a middle-upper Messinian seismic unit of transparent seismic facies or with seismic reflections of very low amplitude, locally underlain by high-amplitude reflections (Figs. 2 and 3). It has a relatively homogenous reflection configuration, in sheeted or draped geometries. The base is erosional at basin margins with locally high-amplitude chaotic facies (Fig. 3b) with a "gull-wing" geometry (sensu Wynn et al. 2007) and onlap to downlap terminations (Fig. 3c). The basal boundary could also be conformable on older successions in the basin centres (Fig. 2b). Within the Offshore Gharb basin, the transparent reflections are interrupted by intervals of high-amplitude convergent-by-thinning facies in the basin centre and high-amplitude chaotic facies at the basin margin (Fig. 2b and 3c), whereas away from the basin this unit can be observed as draping facies at the margins (Fig. 3c). Across the upper to middle slope of the Gulf of Cádiz, the tabular distribution of the middle to upper Messinian unit is also punctuated by structural highs (Fig. 2a) and areas of erosion (Fig. 4), or depocenters with the presence of high-amplitude chaotic or convergent facies, most prominently the eastern section of the Deep Algarve basin and the Offshore Gharb basin (Figs. 2b and 3a). 
Fig. 3 Seismic profiles indicating the distribution of the middle-upper Messinian unit across southern West Iberian margin (WIM): a PD00-608; b Southwest Iberian margin (SWIM): S81-N27 and S81N25 and c Northwest Moroccan margin (NWMM): GHR10-6 (uninterpreted seismic profiles in Fig. S3 - supplementary material)

\section{-2.0 SSW}

TWT ". " Basal Foredeep Unconformity (BFU)
(s) " " - Upper boundary (5.33 Ma) (MPB)

- 2.5 " " " Lower boundary ( 6.4 Ma)

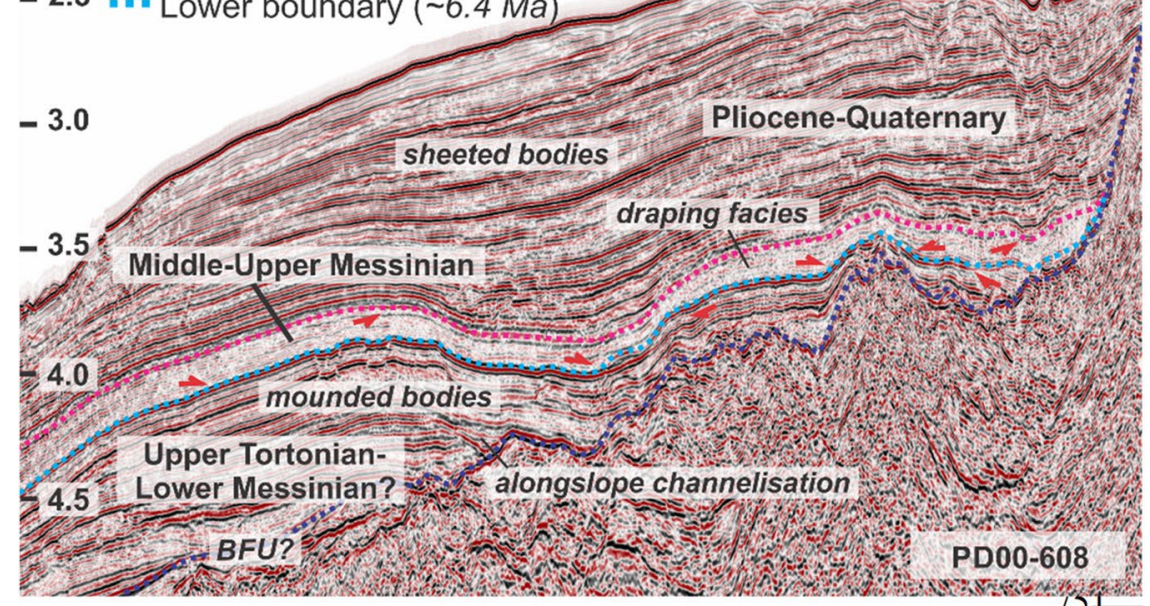

TWT SE $\quad \mathrm{NW}$
(s)
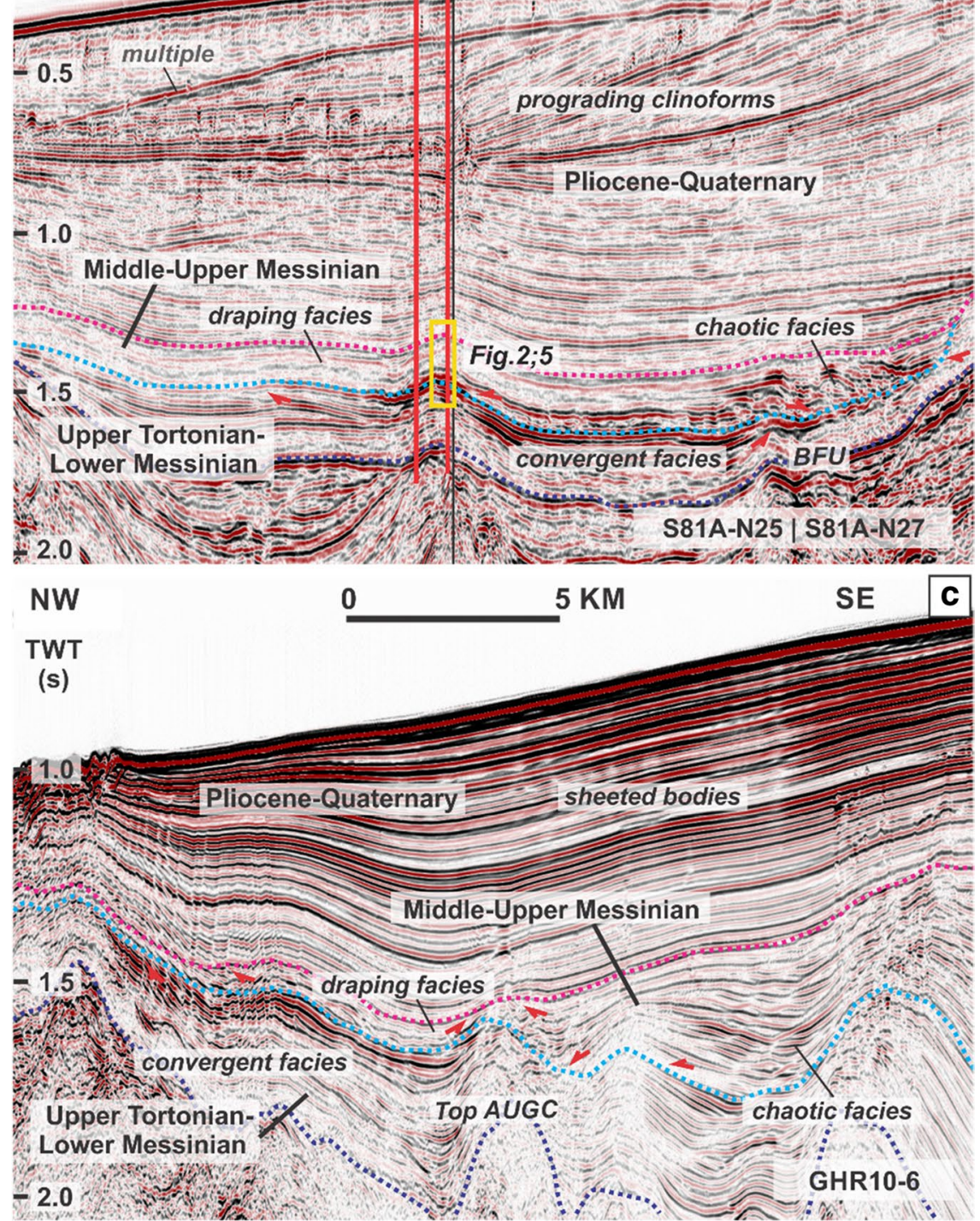
Fig. 4 Time thickness (TWT) map of the middle-upper Messinian unit across Northwest Moroccan (NWMM), Southwest Iberian (SWIM) and southern West Iberian (WIM) margins (contour interval: 100ms TWT)

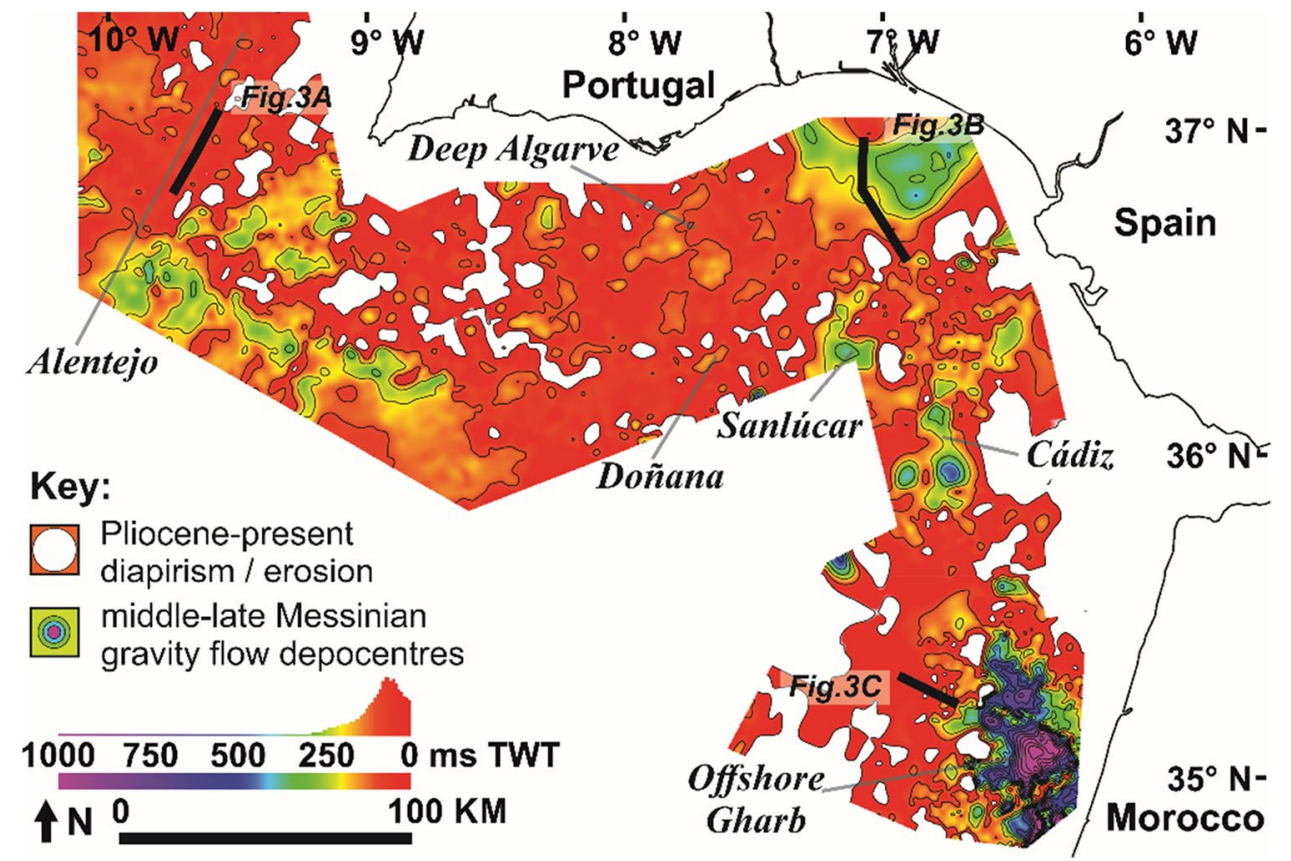

The top boundary of the middle-upper Messinian seismic unit is generally conformable with a change from transparent to a relatively continuous seismic facies (Figs. 2b and 3b) or locally unconformable as truncation surfaces against younger successions (Fig. 3a), represented by the Miocene-Pliocene boundary (MPB; 5.33 Ma; sensu Hernandez-Molina et al. 2016). The Pliocene-Quaternary (5.33 Ma-present) succession above consists of lowermost Pliocene low- to moderateamplitude parallel continuous facies in the basin centres or lower Pliocene high-amplitude chaotic facies on the basin margins truncating the lowermost Pliocene units. They are overlain by upper Pliocene-Quaternary cyclical alternation of low- to high- amplitude sequences in sheeted to mounded geometries associated with alongslope channels (Fig. 3a and c) or prograding clinoforms in the north- and southeast originating from lower Guadalquivir and Onshore Gharb basins, respectively (Fig. 3b).

The contrast in seismic facies between the middle-upper Messinian unit with the upper Tortonian-lower Messinian and Pliocene-Quaternary succession below and above, respectively, provides a distinctive signature for regional stratigraphic correlation across the Gulf of Cádiz towards the southern part of the West Iberian margin (Figs. 2 and 3 ) and can be considered as a regional marker horizon or stratigraphic unit. The middle to upper Messinian unit has an average thickness of $100 \mathrm{~ms}$ TWT (with a range of 50-150 ms TWT), distributed uniformly across the upper to middle continental slope, as shown by the time thickness map of the middle to late Messinian unit (Fig. 4). An exception is observed for the Offshore Gharb basin in the Northwest Moroccan margin, with the distribution of the middle to upper Messinian unit reaching up to $1200 \mathrm{~ms}$ TWT in thickness (Figs. 2b and 4). Likewise, a thicker distribution for the upper Tortonian-lower Messinian succession is observed for the Northwest Moroccan margin and the southern part of the West Iberian margin (500-1000 ms TWT), in contrast to the Southwest Iberian margin (250-500 ms TWT).

\section{Borehole correlation}

Correlation of the middle to upper Messinian unit to borehole data indicates fossiliferous marls to clays with distinct bioturbation, containing few lithic coarser particles (HernandezMolina et al. 2014; van der Schee et al. 2016), with a mean interval velocity $\left(\mathrm{V}_{\mathrm{int}}\right)$ of $\sim 2290-2570 \mathrm{~m} \mathrm{~s}^{-1}$ based on checkshot data from Algarve-2 and GCMPC-1. In the Offshore Gharb basin, this interval is recorded in Anchois-1, Deep Thon-1 and Merou-1 as very shaly or dirty unconsolidated sands with intercalations of clays (Repsol S.A. 2013). Bioand cyclo-stratigraphic dating (Figs. 2, 5 and 6; Table S1) shows deposition of the unit spanning an interval of $\sim 1.1 \mathrm{Ma}$ (>6.37-5.33 Ma), with the base predating the First Occurrence (FO) Globorotalia margaritae, Last Regular Occurrence $(\mathrm{LaO})$ or Last abundant Occurrence $(\mathrm{LaO})$ Globorotalia miotumida events dated 6.31 to $6.35 \mathrm{Ma}$, and the sinistral to dextral coiling change of the Neogloboquadrina acostaensis event dated 6.37 Ma (Krijgsman et al. 2004).

\section{Quantitative constraint on changes in the oceanographic system}

Assuming an absence of contourite deposition within the seismic resolution of our dataset, the critical requirement for 
Fig. 5 Chronology of middleupper Messinian unit (right) and correlation with Mediterranean and Atlantic chronostratigraphy (Flecker et al. 2015; Krijgsman et al. 2018), 100-kyr and filtered 400-kyr eccentricity curves based on orbital solution $\mathrm{La} 04$ (Laskar et al. 2004), gamma ray logging in measured depth (MD) with biostratigraphy of well GCB-3 (Ledesma 2000) in $\mathrm{MD}$ and metres below sea level (mbsl)

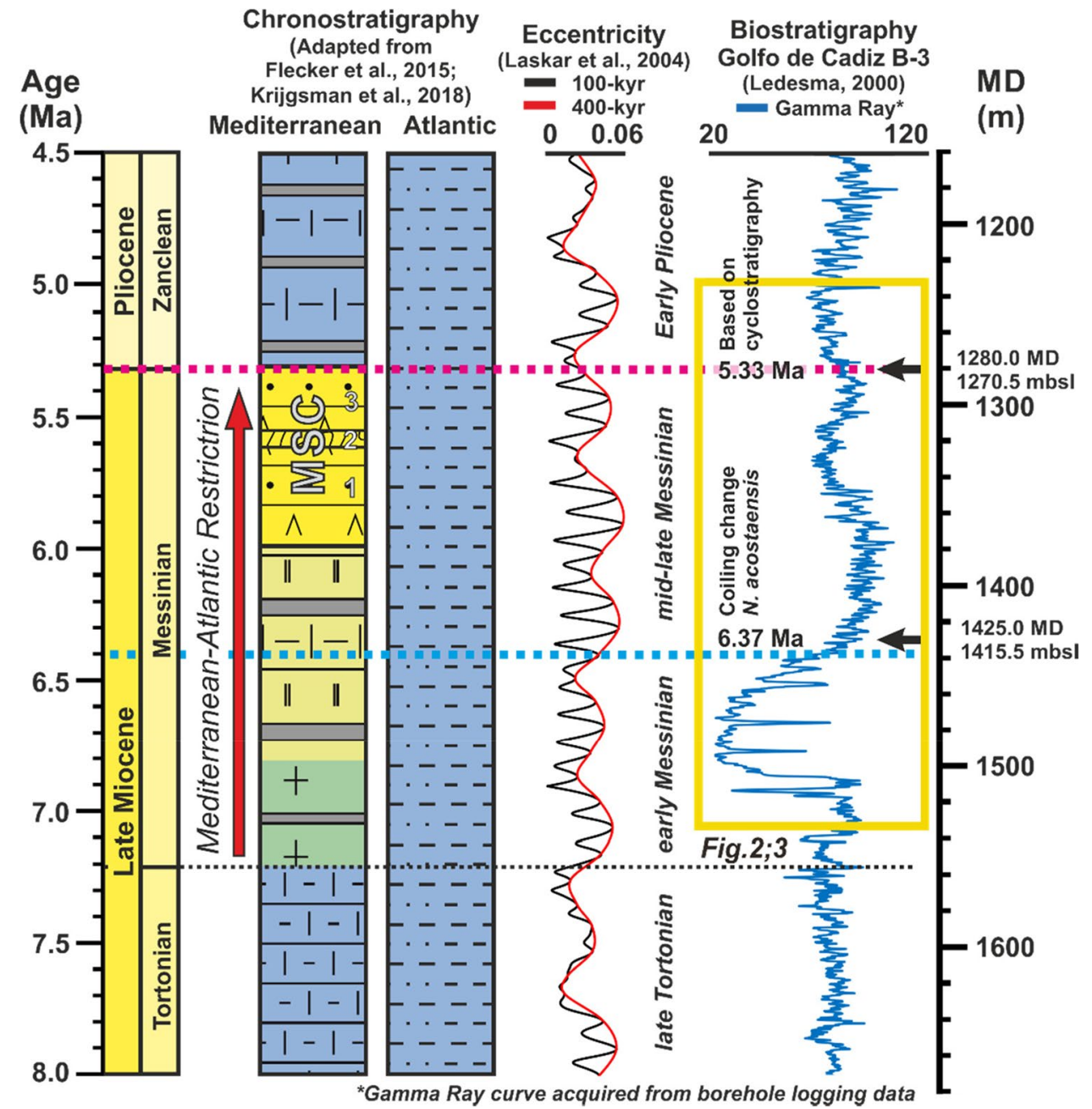

a continuing MOW in the Gulf of Cádiz is the flow velocity threshold of $0.2 \mathrm{~m} \mathrm{~s}^{-1}$ for the onset of winnowing and accumulation of sands (McCave and Hall 2006). Additionally, the $0.15 \mathrm{~m} \mathrm{~s}^{-1}$ threshold where winnowing and silty bedform construction begins (Culp et al. 2020; McCave et al. 2017) is considered. Three scenarios would permit MOW to continue across the Mediterranean-Atlantic water mass exchange but are invisible under the resolution of our seismic analysis: (A) a very small plume (due to considerably reduced flux), (B) a plume flowing very slowly and $(\mathrm{C})$ the plume has moved out of the analyzed area. All three possibilities are investigated. Unless one of these scenarios is capable of producing the sedimentary features observed above, the exchange must have been different from that found today.

Two critical constraints on the system are revealed by Eqs. (1)-(2) (presented in Material and methods), which reflect two inverse relationships: firstly between flux and salinity and secondly between salinity and ambient water entrainment. During the salinification of the Mediterranean, small fluxes of the Mediterranean-Atlantic water mass exchange at the sill correlate to high salinity in the outflowing Mediterranean water (via Eq. (1)). This relationship is explored in detail in Simon and Meijer (2015), and we adopt their conclusions here. Accordingly, a high salinity or density in the outflowing Mediterranean water would result in a high-velocity MOW (via Eqs. (5) and (6)), an intense frictional mixing with ambient water as it passes over the sill of the MediterraneanAtlantic gateways (via Eq. (3)) and hence a vigorous formation of AMW (Rogerson et al. 2012b). Consequently, as the flux of MOW ( $\left.Q_{\text {MOW }}\right)$ falls, its mixing or entrainment behaviour ( $\Phi$ ) also changes (via Eq. (2)). Where $Q_{\text {MOW }}$ is below modern values $(\sim 0.68 \mathrm{~Sv})$, these influences balance, providing the counter-intuitive result that the flux of $\operatorname{AMW}\left(Q_{\mathrm{AMW}}\right)$ is almost invariable. The behaviour is best illustrated via the relationship between $\Phi$ (Phi) and velocity (see Fig. S1 in supplementary material). Consequently, a very small flux of very saline water would, under a first approximation, generate a geostrophic current similar to today and hence a contourite depositional system in the Gulf of Cádiz.

This inverse and non-linear relationship between MOW salinity and entrainment of ambient Atlantic water complicates the relationship of the Mediterranean-Atlantic water mass exchange at the sill and the expected response in both the Gulf of Cadiz and the Mediterranean to changes in other 

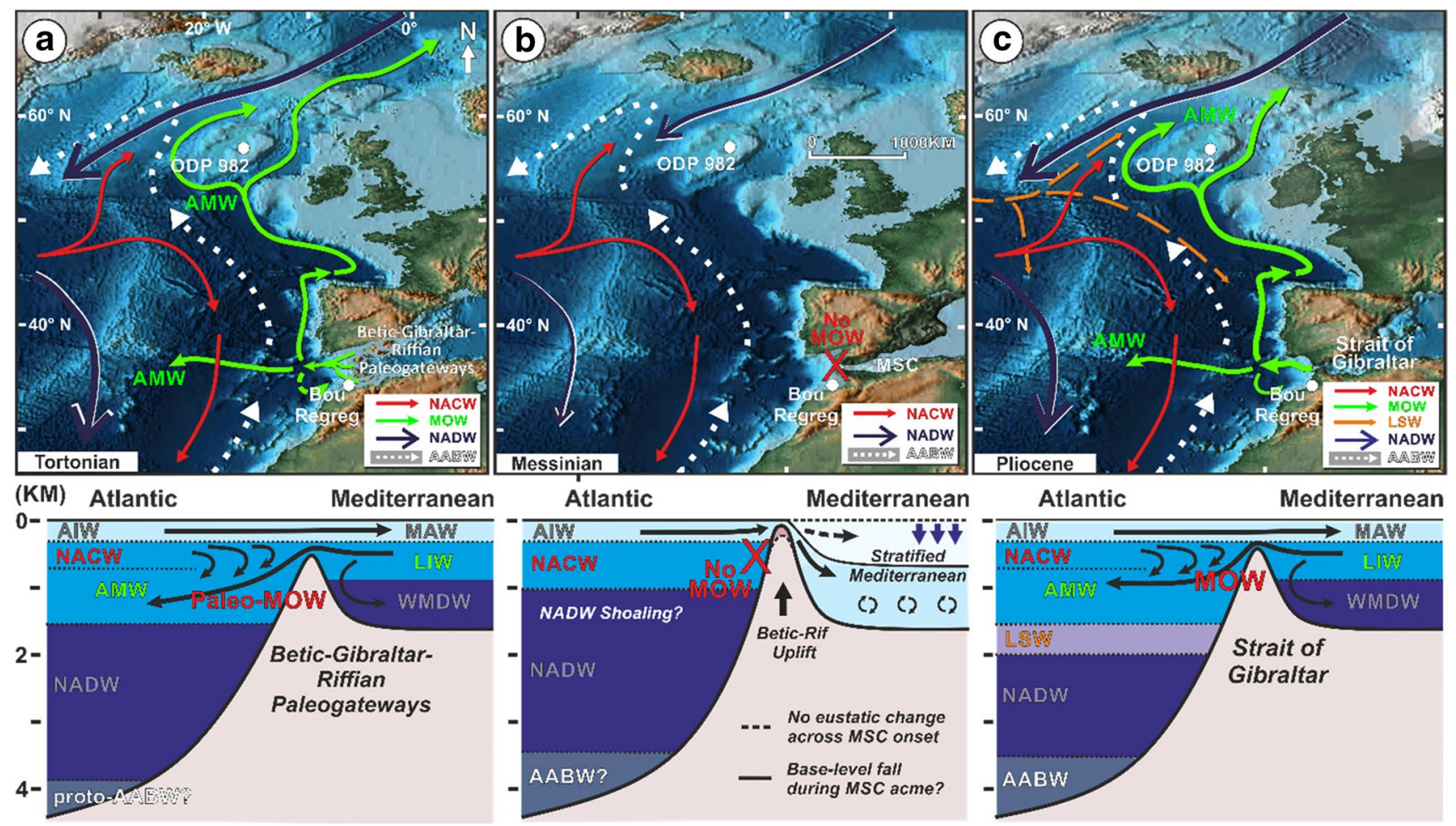

Fig. 6 Scheme of the effect of Mediterranean-Atlantic restriction on the Atlantic Meridional Overturning Circulation (AMOC) during the a Tortonian, b Messinian and $\mathbf{c}$ Pliocene. Paleogeographic reconstruction and Mediterranean-Atlantic gateway configuration adapted from Scotese (2014) and Krijgsman et al. (2018), respec-

oceanographic conditions. Under freshening scenarios, a reduced salinity or density, and hence velocity (via Eqs. (5) and (6)), for the MOW flowing into the Atlantic would suppress entrainment (via Eq. (3)), resulting in an almost unchanged AMW compared to pure MOW post-mixing. This control essentially acts as a negative feedback to changes in the system, which maintains the physical size of the flux. Consequently, a slower outflow would reflect a less dense water mass in the Mediterranean. Overall, the resulting dynamics between the physical properties of the Mediterranean-Atlantic water mass exchange described above are significant for constraining scenarios to discuss the possibility of a continuing outflow across the Mediterranean-Atlantic gateways, complementary to our observations in the seismic and sedimentary interpretation presented in this study.

\section{Discussion}

\section{Stratigraphic and sedimentary interpretation}

The middle to upper Messinian unit ( 6.4-5.33 Ma) is equivalent to the previously described lower section of Marismas Sequence in Riaza and Martínez del Olmo (1996), tively. (NACW: North Atlantic Central Water; MOW: Mediterranean Outflow Water; LSW: Labrador Sea Water; NADW: North Atlantic Deep Water; AABW: Antarctic Bottom Water; AMW: Atlantic-Mediterranean Water)

Unit M3 in Maldonado et al. (1999), Unit MW3' in Roque (2007), Subunit U1B in Rodrigues (2017) and Subunit E2 in Lopes et al. (2006). Similar successions are found in the subsurface of the onshore Guadalquivir basin as Gibraleón clays (Sierro et al. 1996) or Unit C in Ledesma (2000) and in the Onshore Gharb basin (Capella et al. 2017) when they were marine embayments following gateway closures (Martín et al. 2009; Ivanovic et al. 2013). These previous works interpreted similar seismic and sedimentary characteristics for the middle to upper Messinian unit (e.g. transparent zones and thick clay deposits) and confirm its stratigraphic position in the margin.

The seismic and sedimentary facies, and the widespread uniform and tabular distribution of the middle to upper Messinian unit across the continental margins (Figs. 2 and 3 ), imply dominant deposition of hemipelagic settling in the absence of alongslope transport. A higher estimated rate of accumulation $\left(5.2-17.5 \mathrm{~cm} \mathrm{ka}^{-1}\right)$ compared to the average hemipelagic sedimentation rate $\left(2 \mathrm{~cm} \mathrm{ka}^{-1}\right.$, McCave and Hall 2006) could be due to a higher influx of allochthonous terrigenous material on the continental slopes (Henrich and Hüneke 2011). Higher sedimentation rates within the intraslope basins, such as the eastern Deep Algarve (Fig. 3b) and Offshore Gharb (Figs. 2b and 3c) basins, are due to 
interruption in the background sedimentation by interbedded deposition of deep-water turbidite channel levees and lobes or debrites by gravity flow originating from the adjacent margins or from the Guadalquivir and Onshore Gharb basins, respectively (Ledesma 2000). This is indicated by the interpretation of adjoining development of local intervals of high-amplitude chaotic to channel facies on the basin margin and high-amplitude convergent facies locally within the basin centres, as opposed to the transparent draping facies observed regionally across the margin. In the Offshore Gharb basin, the middle-upper Messinian unit consists of a distal turbidite depositional environment of deep-water channels or lobes interbedded with hemipelagic drapes, as interpreted in the Anchois-1, Deep Thon-1 and Merou-1 wells (Repsol S.A. 2013).

Underlying the middle to upper Messinian unit, contourite deposits are distributed onshore and offshore Morocco (Capella et al. 2017; de Weger et al. 2020) as well as in the southern part of the West Iberian margin (Rodrigues 2017) due to the MOW. This indicates an active exchange through the Riffian Corridor until early Messinian, whereas synchronous MOW influence in the Deep Algarve and Guadalquivir basins has not been reported to date. The fact that the upper Tortonian-lower Messinian sequence in the Northwest Moroccan margin is thicker than in the Southwest Iberian margin could also reflect higher sedimentary input with an active MOW through a connected Riffian but a dormant Betic Corridor. However, because of the absence of field evidence onshore Morocco for a marine connection above Lower Messinian deposits (Capella et al. 2019), a shift in MOW circulation through the Strait of Gibraltar cannot be excluded (Krijgsman et al. 2018) with currently available drilling information.

Meanwhile, the top of the middle to upper Messinian unit relates to the end of the MSC, marking a lithological shift from middle to late Messinian hemipelagic conditions into lowermost Pliocene contourite deposits formed by the initiation of weak MOW through the Strait of Gibraltar from 5.33 to $3.2 \mathrm{Ma}$ (Hernández-Molina et al. 2016), with the presence of contourite bigradational sequences directly above the Miocene-Pliocene boundary and an abrupt change in sedimentation rate from 10 to $27 \mathrm{~cm} \mathrm{ka}^{-1}$ (van der Schee et al. 2016). This change is in agreement with the instantaneous return to open marine connection observed in the Mediterranean (Roveri et al. 2014). The middle to late Messinian and lowermost Pliocene sediments could also be truncated by younger lower Pliocene gravity flow deposits, either channel-filled turbidites, debrites or slope fans originating from the margins ( 5.2-3.8 Ma) (Ducassou et al. 2016; Sierro et al. 2008). They are caused by compressional tectonics superimposed upon glacio-eustatic variation (Pérez-Asensio et al. 2018; Sierro et al. 2008).

\section{Quantitative testing of paleoceanographic conditions through the hypothetico-deductive method}

The finding that contourite deposition is not evidenced within the Gulf of Cádiz at seismic scale during the deposition of the middle to upper Messinian unit can be interpreted in several ways. It is even possible that MOW flow did continue, despite not being resolved in our body of data. Here, the viability of continuing but changed along slope flow is explored quantitatively using the simple representation of the plume outlined in the "Materials and methods" section, and the physical constraints on the behaviour of the system described in the "Results" section. Below we discuss the three scenarios put forth in the "Results" section and possible no-analog exchanges as an explanation for our observations at the end of this section.

\section{Could there be a very small flux?}

Given the necessity for the conservation of salt and mass in marginal basin exchanges like the Mediterranean-Atlantic connection at the Strait of Gibraltar, a reduced flow of water must result in greater density (Bryden et al. 1993). The absolute magnitude of the fluxes would then reflect the underlying control from the net freshwater export flux for the Mediterranean basin, which is $0.05 \mathrm{~Sv}$ (Bethoux and Gentili 1999). This control has been modelled for the Messinian context (Simon and Meijer 2015), and a small flux exchange is highly consistent with the evolution of a more saline Mediterranean water mass. Under halitedepositing conditions (Roveri et al. 2014), the flux could be orders of magnitude less than today. As described in the "Results" section, the small flux would lead to a high density and velocity MOW with more intense mixing and the subsequent vigorous formation of AMW, generating a geostrophic current capable of forming a contourite depositional system in the Gulf of Cádiz similar to that observed during the Pliocene and Quaternary (Hernández-Molina et al. 2014; 2016). Thus, while superficially attractive, it is not likely that the absence of contourite deposits in the cores and seismic presented in this study can be explained by a very small flux at the gateway.

\section{Could there be a slower flow?}

In terms of the paleo-AMW plume, the maximum flow velocity in the region during the middle to late Messinian consistent with our observations (absence of contourite depositional system) is $0.2 \mathrm{~m} \mathrm{~s}^{-1}$ (McCave and Hall 2006), which represents the maximum geostrophic velocity $\left(U_{\text {geo }}\right)$ experienced on the slope (O'Neill-Baringer and Price 1997). 
This is considerably lower than velocities observed in the region today (Sánchez-Leal et al. 2017), which are $\sim 1 \mathrm{~m} \mathrm{~s}^{-1}$ where sandy contourites are forming and in excess of $1.4 \mathrm{~m} \mathrm{~s}^{-1}$ in regions of abrasion (O'Neill-Baringer and Price 1999). As shown in the "Results" section, a low-velocity MOW or AMW would directly reflect a less dense Mediterranean water mass. This implies that the Mediterranean was much less salty during the middle to late Messinian than in the late Tortonian to early Messinian, which is at odds with the empirical evidence. Conceptually, some loss of density could be traced to the warming of the Mediterranean relative to the Atlantic, but such a regional difference would have to be unrealistically large (up to several degrees) and could still not account for the latest Miocene when halite or gypsum was deposited in the Mediterranean. Moreover, a slower maximum flow velocity threshold $\left(0.15 \mathrm{~m} \mathrm{~s}^{-1}\right)$ would mean a more significant reduction of salinity in the Mediterranean. Hence, we find no conditions under which our seismic observations are explained by a very slow-moving plume.

\section{Could the plume have moved?}

As the position of the gateway moved, the contourite deposition downstream of it must have moved as well. The data covers the most northerly (Figs. $2 \mathrm{a}$ and $3 \mathrm{~b}$ ) to the most southerly gateway recognized (Figs. $2 \mathrm{~b}$ and $3 \mathrm{c}$ ), fully capturing the possibility of a change in gateway position, thus eliminating this possibility. It might be that the MOW plume moved deeper down the slope, coming to lie basinward of the seismic data presented. For the Late Quaternary, such alterations have been documented (Schönfeld et al. 2003; Llave et al. 2006; Rogerson et al. 2012a). Given the operations of mixing and/or entrainment to counter changes in the density of outflowing water (see discussion above), such settings would not arise from changes in the Mediterranean basin itself but rather from a weakening of the Atlantic Meridional Overturning Circulation (Rogerson et al. 2012a). In order for the AMW to reach water depths beyond the range of the seismic data presented here, the AMOC would have had to weaken to approximately its conditions during the Last Glacial Maximum (Rogerson et al. 2005). A slow AMOC may have occurred in warm periods of the Early Miocene, but there is no evidence in favour of this hypothesis for the Late Miocene (Steinthorsdottir et al. 2020), and the relatively low volume of northern polar ice at the time, as compared to the Late Quaternary Heinrich Events, makes a "thermohaline crisis" scenario in the Atlantic difficult to envisage. We therefore do not speculate about a sustained period of very low AMOC throughout the deposition of the middle to upper Messinian unit (up to several hundreds of thousands of years) in support of a deepwater flow at this time (Steinthorsdottir et al. 2020). Unless such evidence of sustained low Atlantic overturning during the middle to late Messinian is presented, the AMW plume could not be expected to lie lower on the slope than the region of the seismic data we examined.

\section{Was the Mediterranean-Atlantic water mass exchange different from that of today?}

Recent consensus regarding the evaporite-depositing phases in the latest Miocene evokes extremely stratified Mediterranean basins (Yoshimura et al. 2016), with exceptionally dense brines occupying deep areas below sills connecting with the Atlantic. However, these deep brine bodies would remain within a Mediterranean overturning circulation, where quantitative representations of the basin demonstrate that deep brines would have continued to mix into overlying waters (Simon and Meijer 2017) and as part of that advection were likely directly drawn up to sill depth by frictional Bernoulli aspiration (Rogerson et al. 2012b). Advection of deep waters is required to balance the water volume provided to finite deep basins by convection (Simon and Meijer 2017); without the Mediterranean overturning circulation, the mass of salt held in water within the deep basins could rapidly be exhausted and evaporite deposition would be replaced by sapropel deposition. The extreme stratification scenarios provided by Simon and Meijer (2017) are therefore consistent with the quantitative representation of the AMW plume used here and do not suffice to explain the lack of a contourite depositional system in the Gulf of Cádiz.

By discarding other reasonable scenarios through this hypothetico-deductive method, we find that the most likely explanation for our seismic observations in the Gulf of Cádiz and the non-desiccation of the Mediterranean during the deposition of the middle to upper Messinian unit is inflowwithout-outflow. This implies that the interface between the surficial and intermediate (e.g. LIW) water masses in the Mediterranean had already been drawn to or below sill depth, while the Atlantic sea surface remaining above it provided a continuous unidirectional eastward flow of relatively freshwater into the Mediterranean, balancing evaporation. Still, we are unable to affirm whether there were sporadic outflows across the Mediterranean-Atlantic gateway during the middle to upper Messinian, which may be required to maintain salinity below evaporitic saturation (Roveri et al. 2014), as the primary impact would be deep scouring close to the strait (Siddall et al. 2004) later masked by Pliocene erosion (Fig. 4). We likewise find no positive indication of changes in seismic facies in the middle to upper Messinian unit within the seismic resolution of our dataset that could account for sporadic outflows in parts of the margins with a more conformable succession (Fig. 2). Further research is necessary to determine whether this period of apparently no MOW nor AMW plume activity is punctuated by shorter returns to two-way water mass exchange or whether salt was 
lost from the Mediterranean basin by other means, such as an earlier-than-anticipated onset of evaporite deposition in the deep Eastern Mediterranean basins.

\section{Implications of the Late Miocene Mediterranean-Atlantic gateway restriction}

The basal unconformity of the middle to late Messinian unit $(\sim 6.4 \mathrm{Ma})$ is linked to an onset of dominantly hemipelagic depositional environment. This seismic and lithologic change suggests absent or intermittent bottom currents without the influence of MOW through the Late Miocene paleo-gateways before the onset of MSC evaporite precipitation and deposition in the Mediterranean. The reduced MOW in the Gulf of Cádiz during the middle to late Messinian was probably due to the shallowing of the sill in the paleo-gateway by tectonic uplift (Krijgsman et al. 1999). Accordingly, the threshold depth allowed solely Atlantic inflow (Capella et al. 2019; Flecker et al. 2015) or intermittent outflow incapable of significantly reworking sediments on the slope of the Gulf of Cádiz since at least $6.37 \mathrm{Ma}, \sim 400 \mathrm{kyr}$ preceding the onset of the MSC (Manzi et al. 2018). This scenario is consistent with a shift from paleo-MOW to paleo-Atlantic bottom waters in the Onshore Gharb basin between $\sim 6.64$ and $6.44 \mathrm{Ma}$, based on Neodymium ( $\mathrm{Nd}$ ) isotope values in the Bou Regreg valley succession in the Riffian Corridor (Salé Briqueterie, Ain El Beida and Oued Akrech; Fig. 7; Ivanovic et al. 2013). Regional uplift and tectonism (Duggen et al. 2003) could also have driven the formation of the turbidites observed at the base of the middle to upper Messinian unit, with turbidite channels scouring into the lower Messinian unit. The reduction of MOW we report at the $\sim 6.4$ Ma mark also coincides with a $400-\mathrm{kyr}$ eccentricity minima of the orbital solution by Laskar et al. (2004) (Fig. 5) and supports a stepwise nature for the progressive restriction of the Mediterranean-Atlantic gateway, further consolidating the 400-kyr periodicity orbital forcing superimposed on a gradual tectonic trend as the mechanism behind gateway closure (Hilgen et al. 2007) and changes in the dominant depositional style. An astronomical link to the long eccentricity orbital forcing has been proposed for the evolution of stratigraphic events in this region leading up to the MSC (Roveri et al. 2014), namely the Tortonian salinity crisis (7.8-7.6 Ma) (Krijgsman et al. 2000), the stepwise restriction of Mediterranean-Atlantic connection $(\sim 7.2$ and $\sim 6.8 \mathrm{Ma}$ ) (Kouwenhoven et al. 2003), the onset of MSC (5.97 Ma) (Manzi et al. 2018) and the "Messinian Gap" or MSC acme event (5.6-5.55 Ma) (Krijgsman et al. 1999). The gateway restriction, along with paleoceanographic changes, could explain the concurrent phylogenetic divergence of Mediterranean-New World monk seals around 6.3 Ma, similar to the effect of the Central American seaway closure on CaribbeanHawaiian monk seal divergence (Scheel et al. 2014).

In the Mediterranean, the gateway restriction was also recorded progressively, leading up to the weakening of the MOW at $\sim 6.4 \mathrm{Ma}$, firstly by a significant reduction of deepwater ventilation immediately after the Tortonian-Messinian boundary $(7.15 \mathrm{Ma})$, followed by an intensification of bottom water stagnation and water stratification (6.7 Ma; Blanc-Valleron et al. 2002; Kouwenhoven et al. 1999; 2003). These changes were accompanied by a lesser diversity of calcareous planktons (Sierro et al. 2003). Then, deposition of aplanktic levels related to more adverse conditions of restriction with increased salinity $(>50 \mathrm{~g} / \mathrm{L})$ took place since 6.4 Ma (Sierro et al. 2008). This period (6.45-6.29 Ma) is furthermore characterized by more negative and unstable $\delta^{18} \mathrm{O}$ values in the Mediterranean, suggesting stronger dilution by continental waters, pointing to a severe isolation of the Mediterranean basin, which was no longer regulated by oceanic input but by climatic fluctuations (Blanc-Valleron et al. 2002). The widespread precipitation of authigenic calcite, dolomite and/or aragonite in the Mediterranean between 6.3 and $5.97 \mathrm{Ma}$, prior to the deposition of MSC evaporites, moreover indicates an increasingly restrictive and supersaturated environment (Blanc-Valleron et al. 2002; Sierro et al. 2003). A continuous but reduced surficial Atlantic inflow into the Mediterranean could contribute to varying salinity levels around the upper tolerance limit of foraminifera $(50 \mathrm{~g} / \mathrm{L})$ but below the threshold of gypsum deposition (130 g/L; Flecker et al. 2015) in the Mediterranean marginal basins; meanwhile, the absence of outflow to the Atlantic requires salt being lost from the Mediterranean basin through other means, from the initiation of the transparent unit until the onset of MSC ( 6.4-5.97 Ma). In the deeper basins, euxinic shales in the pre-MSC interval (Roveri et al. 2014) extending into the first stage of MSC (de Lange and Krijgsman 2010) indicate anoxic and sulphidic bottom water conditions that could impede the precipitation of gypsum even where salinity was strongly enhanced. Reduced conditions in the deep basin would also explain the synchronous onset of marginal gypsum and basinal halite precipitation, reaching saturations of 130 and $350 \mathrm{~g} / \mathrm{L}$, respectively (Meilijson et al. 2018). Such a scenario still requires a sink of salt from the basin, however, either via sproradic outbursts into the Atlantic too subtle for seismic reflection data to resolve or owing to an earlier-than-anticipated onset of salt deposition in the deep Mediterranean basins. Either hypothesis will need to be tested via new coring and research.

The transition from contouritic to hemipelagic sedimentation in the Miocene would give rise to changes in the Atlantic paleoceanographic regime (Fig. 6). A restricted Mediterranean-Atlantic connection and an absence or intermittence of MOW during the middle to late Messinian would have significantly reduced Atlantic water entrainment and halted 
the formation of the AMW (Rogerson et al. 2012b). This would alter the strength, structure and possibly the position of the Azores Front (Ozgokmen et al. 2001) and destabilize the AMOC (Ivanovic et al. 2014; Pérez-Asensio et al. 2012; Sierro et al. 2020). Assuming that the buoyancy export during the early Messinian was similar to that existing today, a loss of MOW would reduce the buoyancy loss within the North Atlantic by $\sim 8.53 \times 10^{5} \mathrm{~kg} \mathrm{~s}^{-1}$, which is a change of the same magnitude as that arising from Anthropocene Arctic sea ice loss (Liu et al. 2019). A unidirectional loss of salt into the Mediterranean via an inflow-without-outflow scenario at Gibraltar during the Messinian would also differ from a small net inflow of salt relative to the total inflowoutflow budget under the present two-way exchange scenario. This would likely result in anomalously low salinity in the adjacent Northeastern Atlantic and possibly the weakest AMOC since the closure of the connection between the Mediterranean and the Indian Ocean during the middle Miocene (de la Vara et al. 2013). A revised astronomical age model for ODP Site 982 in the North Atlantic (Fig. 6; Drury et al. 2018) correlated to the Ain El Beida section in the Bou Regreg Valley (Fig. 6; van der Laan et al. 2005) indicates benthic excursions of $\delta^{18} \mathrm{O}$ and $\delta^{13} \mathrm{C}$ in the Atlantic intermediate water depths (500-1500 m; sensu Emery and Meincke 1986) around $\sim 6.4 \mathrm{Ma}$ (Drury et al. 2018). The higher average $\delta^{18} \mathrm{O}$ and $\delta^{13} \mathrm{C}$ values suggest colder conditions (Drury et al. 2018) and could testify to the removal of warm and saline AMW and glacial shoaling of the NADW (Gebbie 2014; Fig. 6b). This major paleoceanographic change is responsible for the enhanced subsurface and atmospheric cooling in the mid-latitudes of the Northern Hemisphere (Boulton et al. 2014; Ivanovic et al. 2014), which coincides with dynamic ice sheet expansion and strengthening of the cryosphere-carbon cycle coupling between 6.4 and $5.4 \mathrm{Ma}$ (Drury et al. 2018; Herbert et al. 2016).

\section{Conclusions}

The widespread distribution of a predominantly hemipelagic middle to upper Messinian unit along the continental slope in the Gulf of Cádiz and the southern part of the West Iberian margin can be viewed as the sedimentary response to an absence or intermittence of intermediate circulation. This implies no continuous outflow of the Mediterranean-Atlantic exchange at least $400 \mathrm{kyr}$ preceding the MSC, simultaneous to progressive gateway restriction, and correlates to AMOC weakening and North Atlantic cooling in the latest Miocene. An alternative interpretation is that the AMOC was severely reduced throughout this period, causing the MOW plume to settle at great depth. As this is not consistent with existing reconstructions of the Atlantic during the Late Miocene, we support the former scenario.
Either as a means of explaining the transparent unit via deep settling or as a consequence of inflow-without-outflow causing major palaeoceanographic changes throughout the North Atlantic, the evolution of the Mediterranean at this time seems to be inextricably bound to the evolution of AMOC. One important outcome of this study is the recognition of the disadvantages of considering the two basins in isolation and of the need to integrate conceptual models of Atlantic paleoceanography with Mediterranean geological models for the latest Miocene.

Supplementary Information The online version contains supplementary material available at https://doi.org/10.1007/s00367-021-00693-9.

Acknowledgments The authors would like to thank the editor and two anonymous reviewers for their constructive comments. This work is conducted in the framework of "The Drifters" Research Group, Royal Holloway University of London, and supported by Royal Holloway college studentship, SCORE (CGL2016-80445-R) and INPULSE (CTM2016-75129-C3-1-R) projects. The authors would also like to extend their grateful thanks to Mr. Mohamed Nahim as Director of Petroleum Exploration (ONHYM) for his support and to ONHYM, Repsol S.A. and TGS-Nopec for permission to use the seismic and borehole data in this work. Datasets for this research are partly included in the literature (Hernández-Molina et al. 2014, 2016; Ledesma 2000; van der Schee et al. 2016), partly available from ONHYM, Repsol S.A. and TGS-Nopec with confidentiality regulations and are not publicly accessible, but are available from the authors upon reasonable request and with permissions of ONHYM, Repsol S.A. and TGS-Nopec.

Open Access This article is licensed under a Creative Commons Attribution 4.0 International License, which permits use, sharing, adaptation, distribution and reproduction in any medium or format, as long as you give appropriate credit to the original author(s) and the source, provide a link to the Creative Commons licence, and indicate if changes were made. The images or other third party material in this article are included in the article's Creative Commons licence, unless indicated otherwise in a credit line to the material. If material is not included in the article's Creative Commons licence and your intended use is not permitted by statutory regulation or exceeds the permitted use, you will need to obtain permission directly from the copyright holder. To view a copy of this licence, visit http://creativecommons.org/licenses/by/4.0/.

\section{References}

Berggren WA (1982) Role of ocean gateways in climate change. In: Climate in earth history. Studies in Geophysics, 118-125. Washington D.C.: National Academy Press

Bethoux JP, Gentili B (1999) Functioning of the Mediterranean Sea: past and present changes related to freshwater input and climate changes. J Mar Syst 20:33-47. https://doi.org/10.1016/S09247963(98)00069-4

Blanc-Valleron M-M, Pierre C, Caulet JP, Caruso A, Rouchy J-M, Cespuglio G, Sprovieri R, Pestrea S, Di Stefano E (2002) Sedimentary, stable isotope and micropaleontological records of paleoceanographic change in the Messinian Tripoli Formation (Sicily, Italy). Palaeogeogr Palaeoclimatol Palaeoecol 185:255-286. https://doi.org/10.1016/S0031-0182(02)00302-4

Boulton CA, Allison LC, Lenton TM (2014) Early warning signals of Atlantic Meridional Overturning Circulation collapse in a fully 
coupled climate model. Nat Commun 5:5752. https://doi.org/10. 1038/ncomms6752

Bryden LH (1993) Sill exchange to and from enclosed seas. In N. F. R. Delia Croce (Ed.), Symposium Mediterranean Seas 2000, Università di Genova, Santa Margherita Ligure, 23-27 September 1991 (pp. 17-41) Genova: Instituto Scienze Ambientali Marine.

Capella W, Flecker R, Hernández-Molina FJ, Simon D, Meijer PT, Rogerson M, Sierro FJ, Krijgsman W (2019) Mediterranean isolation preconditioning the Earth System for Late Miocene climate cooling. Sci Rep 9:3795. https://doi.org/10.1038/s41598-019-40208-2

Capella W, Hernández-Molina FJ, Flecker R, Hilgen FJ, Hssain M, Kouwenhoven TJ, van Oorschot M, Sierro FJ, Stow DAV, Trabucho-Alexandre J, Tulbure MA, de Weger W, Yousfi MZ, Krijgsman W (2017) Sandy contourite drift in the Late Miocene Rifian Corridor (Morocco): reconstruction of depositional environments in a foreland-basin seaway. Sed Geol 355:31-57. https://doi.org/ 10.1016/j.sedgeo.2017.04.004

Culp J, Strom K, Parent A, Romans BW (2020) Sorting of fine-grained sediment by currents: testing the sortable silt hypothesis with laboratory experiments. Earth Arxiv. https://doi.org/10.31223/osf.io/ xec2t[Accessed31/12/2020]

de la Vara A, Meijer PTh, Wortel MJR (2013) Model study of the circulation of the Miocene Mediterranean Sea and Paratethys: closure of the Indian Gateway. Clim Past Discuss 9:4385-4424. https:// doi.org/10.5194/cpd-9-4385-2013

de Lange GJ, Krijgsman W (2010) Messinian salinity crisis: a novel unifying shallow gypsum/deep dolomite formation mechanism. Mar Geol 275:273-277. https://doi.org/10.1016/j.margeo.2010. 05.003

de Weger W, Hernández-Molina FJ, Flecker R, Sierro FJ, Chiarella D, Krijgsman W, Manar MA (2020) Late Miocene contourite channel system reveals intermittent overflow behavior. Geology. https:// doi.org/10.1130/G47944.1

Drury AJ, Westerhold T, Hodell D, Röhl U (2018) Reinforcing the North Atlantic backbone: revision and extension of the composite splice at ODP Site 982. Clim Past 14:321-338. https://doi.org/10. 5194/cp-14-321-2018

Ducassou E, Fournier L, Sierro FJ, Alvarez CA, Zarikian, Lofi J, Flores JA, Roque C (2016) Origin of the large Pliocene and Pleistocene debris flows on the Algarve margin. Mar Geol 377:58-76. https:// doi.org/10.1016/j.margeo.2015.08.018

Duggen S, Hoernle K, van den Bogaard P, Rüpke L, Morgan JP (2003) Deep roots of the Messinian salinity crisis. Nature 422:602-606. https://doi.org/10.1038/nature01551

Emery WJ, Meincke J (1986) Global water masses: summary and review. Oceanol Acta 9:383-391

Flecker R, Ellam RM (2006) Identifying Late Miocene episodes of connection and isolation in the Mediterranean-Paratethyan realm using Sr isotopes. Sed Geol 188-189:189-203. https://doi.org/10. 1016/j.sedgeo.2006.03.005

Flecker R, Krijgsman W, Capella W, de Castro Martíns C, Dmitrieva E, Mayser JP, Marzocchi A, Modestou S, Ochoa D, Simon D, Tulbure M, van den Berg B, van der Schee M, de Lange G, Ellam R, Govers R, Gutjahr M, Hilgen FJ, Kouwenhoven T, Lofi J, Meijer P, Sierro FJ, Bachiri N, Barhoun N, Chakor Alami A, Chacon B, Flores JA, Gregory J, Howard J, Lunt D, Ochoa M, Pancost R, Vincent S, Zakaria Yousfi M (2015) Evolution of the Late Miocene Mediterranean-Atlantic gateways and their impact on regional and global environmental change. Earth Sci Rev 150:365-392. https://doi.org/10.1016/j.earscirev.2015.08.007

Gebbie G (2014) How much did Glacial North Atlantic Water shoal? Paleoceanography 29:190-209. https://doi.org/10.1002/2013P A002557
Henrich R, Hüneke H (2011) Hemipelagic advection and periplatform sedimentation. In: H. Hüneke, T. Mulder (Eds.), Deep-sea sediments. Developments in Sedimentology, 63, 353-396. https://doi. org/10.1016/B978-0-444-53000-4.00005-6

Herbert TD, Lawrence KT, Tzanova A, Peterson LC, Caballero-Gill R, Kelly CS (2016) Late Miocene global cooling and the rise of modern ecosystems. Nat Geosci 9:843-847. https://doi.org/10. 1038/ngeo2813

Hernández-Molina FJ, Llave E, Preu B, Ercilla G, Fontan A, Bruno M, Serra N, Gomiz JJ, Brackenridge RE, Sierro FJ, Stow DAV, García M, Juan C, Sandoval N, Arnáiz A (2014) Contourite processes associated with the Mediterranean Outflow Water after its exit from the Strait of Gibraltar: global and conceptual implications. Geology 42:227-230. https://doi.org/10.1130/G35083.1

Hernández-Molina FJ, Sierro FJ, Llave E, Roque C, Stow DAV, Williams T, Lofi J, van der Schee M, Arnáiz A, Ledesma S, Rosales C, Rodríguez-Tovar FJ, Pardo-Igúzquiza E, Brackenridge RE (2016) Evolution of the gulf of Cádiz margin and southwest Portugal contourite depositional system: tectonic, sedimentary and paleoceanographic implications from IODP expedition 339. Mar Geol 377:7-39. https://doi.org/10.1016/j.margeo.2015.09.013

Hilgen FJ, Krijgsman W, Langereis CG, Lourens LJ, Santarelli A, Zachariasse WJ (1995) Extending the astronomical (polarity) time scale into the Miocene. Earth Planet Sci Lett 136:495-510. https://doi.org/10.1016/0012-821X(95)00207-S

Hilgen F, Kuiper K, Krijgsman W, Snel E, van der Laan E (2007) Astronomical tuning as the basis for high resolution chronostratigraphy: the intricate history of the Messinian Salinity Crisis. Stratigraphy 4:231-238

Hodell DA, Curtis JH, Sierro FJ, Raymo ME (2001) Correlation of Late Miocene to early Pliocene sequences between the Mediterranean and North Atlantic. Palaeoceanography 16:164-178. https://doi. org/10.1029/1999PA000487

Hüsing SK, Oms O, Agustí J, Garcés M, Kouwenhoven TJ, Krijgsman W, Zachariasse W-J (2010) On the Late Miocene closure of the Mediterranean-Atlantic gateway through the Guadix basin (southern Spain). Palaeogeogr Palaeoclimatol Palaeoecol 291:167-179. https://doi.org/10.1016/j.palaeo.2010.02.005

Iaccarino SM, Cita MB, Gaboardi S, Gruppini GM (1999) Highresolution biostratigraphy at the Miocene/Pliocene boundary in Holes 974B and 975B, western Mediterranean. Proceedings of the Ocean Drilling Program, Scientific Results 161 (pp. 197-221). College Station, TX: Ocean Drilling Program. https://doi.org/10. 2973/odp.proc.sr.161.247.1999

Ivanovic RF, Flecker R, Gutjahr M, Valdesa PJ (2013) First Nd isotope record of Mediterranean-Atlantic water exchange through the Moroccan Rifian Corridor during the Messinian salinity crisis. Earth Planet Sci Lett 368:163-174. https://doi.org/10.1016/j.epsl. 2013.03.010

Ivanovic RF, Valdes PJ, Flecker R, Gutjahr M (2014) Modelling global-scale climate impacts of the Late Miocene Messinian salinity crisis. Clim Past 10:607-622. https://doi.org/10.5194/ cp-10-607-2014

Knutz PC (2008) Paleoceanographic significance of contourite drifts. In: Rebesco M, Camerlenghi A (Eds.) Contourites. Developments in Sedimentology, 60, 511-535. Amsterdam: Elsevier

Kouwenhoven TJ, Seidenkrantz M-S, van der Zwaana GJ (1999) Deepwater changes: the near-synchronous disappearance of a group of benthic foraminifera from the Late Miocene Mediterranean. Palaeogeogr Palaeoclimatol Palaeoecol 152:259-281. https://doi. org/10.1016/S0031-0182(99)00065-6

Kouwenhoven TJ, Hilgen FJ, van der Zwaan GJ (2003) Late Tortonianearly Messinian stepwise disruption of the Mediterranean-Atlantic 
connections: constraints from benthic foraminiferal and geochemical data. Palaeogeogr Palaeoclimatol Palaeoecol 198:303-319. https://doi.org/10.1016/S0031-0182(03)00472-3

Krijgsman W, Capella W, Simon D, Hilgen FJ, Kouwenhoven TJ, Meijer PTh, Sierro FJ, Tulbure MA, van den Berg BCJ, van der Schee M, Flecker R (2018) The Gibraltar Corridor: watergate of the Messinian salinity crisis. Mar Geol 403:238-246. https://doi.org/ 10.1016/j.margeo.2018.06.008

Krijgsman W, Gaboardi S, Hilgen FJ, Iaccarino S, de Kaenel E, van der Laan E (2004) Revised astrochronology for the Ain el Beida section (Atlantic Morocco): no glacio-eustatic control for the onset of the Messinian Salinity Crisis. Stratigraphy 1:87-101

Krijgsman W, Garcés M, Agustí J, Raffi I, Taberner C, Zachariasse WJ (2000) The 'Tortonian salinity crisis' of the eastern Betics (Spain). Earth Planet Sci Lett 181:497-551. https://doi.org/10. 1016/S0012-821X(00)00224-7

Krijgsman W, Hilgen FJ, Raffi I, Sierro FJ, Wilson DS (1999) Chronology, causes and progression of the Messinian salinity crisis. Nature 400:652-655. https://doi.org/10.1038/23231

Laskar J, Robutel P, Joutel F, Gastineau M, Correia ACM, Levrard B (2004) A long-term numerical solution for the insolation quantities of the Earth. Astron Astrophys 428:261-285. https://doi.org/ 10.1051/0004-6361:20041335

Ledesma S (2000) Astrobiocronología y estratigrafía de alta resolución del Neógeno de la Cuenca del Guadalquivir-Golfo De Cádiz, (Doctoral dissertation). Retrieved from Grupo de Geociencias Oceánicas. (http://oceano.usal.es/wp-content/uploads/sites/30/ 2017/10/SantiagoLedesmaTesis.compressed-1.pdf). Salamanca: Universidad de Salamanca.

Liu W, Fedorov A, Sévellec F (2019) The mechanisms of the Atlantic Meridional Overturning Circulation slowdown induced by Arctic sea ice decline. J Clim 32:977-996. https://doi.org/10.1175/ JCLI-D-18-0231.1

Liu W, Fedorov A, Xie S-P, Hu S (2020) Climate impacts of a weakened Atlantic Meridional Overturning Circulation in a warming climate. Sci Adv 6:eaaz4876. https://doi.org/10.1126/sciadv.aaz48 76

Llave E, Schönfeld J, Hernández-Molina FJ, Mulder T, Somoza L, Díaz del Río V, Sánchez-Almazo I (2006) High-resolution stratigraphy of the Mediterranean outflow contourite system in the Gulf of Cadiz during the late Pleistocene: The impact of Heinrich events. Mar Geol 227:241-262. https://doi.org/10.1016/j.margeo.2005. 11.015

Lopes FC, Cunha PP, Le Gall B (2006) Cenozoic seismic stratigraphy and tectonic evolution of the Algarve margin (offshore Portugal, southwestern Iberian Peninsula). Mar Geol 231:1-36. https://doi. org/10.1016/j.margeo.2006.05.007

Lourens LJ, Antonarakou A, Hilgen FJ, Van Hoof AAM, VergnaudGrazzini C, Zachariasse WJ (1996) Evaluation of the Plio-Pleistocene astronomical timescale. Paleoceanography 11:391-413. https://doi.org/10.1029/96PA01125

Lourens LJ, Hilgen FJ, Shackleton J, Laskar J, Wilson J (2004) The Neogene Period. In: Gradstein F, Ogg J, Simth A (eds) A Geologic Time Scale. Cambridge University Press, London, pp 409-440

Maldonado A, Somoza L, Pallarés L (1999) The Betic orogen and the Iberian-African boundary in the Gulf of Cádiz: geological evolution (central North Atlantic). Mar Geol 155:9-43. https://doi.org/ 10.1016/S0025-3227(98)00139-X

Manzi V, Gennari R, Lugli S, Persico D, Reghizzi M, Roveri M, Schreiber BC, Calvo R, Gavrieli I, Gvirtzman Z (2018) The onset of the Messinian salinity crisis in the deep Eastern Mediterranean basin. Terra Nova 30:189-198. https://doi.org/10.1111/ter.12325
Martín JM, Braga JC, Betzler C (2002) The Messinian Guadalhorce corridor: the last northern, Atlantic-Mediterranean gateway. Terra Nova 13:418-424. https://doi.org/10.1046/j.1365-3121.2001. 00376.x

Martín JM, Braga JC, Aguirre J, Puga-Bernabéu Á (2009) History and evolution of the North-Betic Strait (Prebetic Zone, Betic Cordillera): a narrow, early Tortonian, tidal-dominated, AtlanticMediterranean marine passage. Sed Geol 216:80-90. https://doi. org/10.1016/j.sedgeo.2009.01.005

McCave IN, Hall IR (2006) Size sorting in marine muds: processes, pitfalls, and prospects for paleoflow-speed proxies. Geochem Geophys Geosyst 7:Q10N05. https://doi.org/10.1029/2006GC001284

McCave IN, Thornalley DJR, Hall IR (2017) Relation of sortable silt grain-size to deep-sea current speeds: calibration of the 'Mud Current Meter.' Deep Sea Res Part I 127:1-12. https://doi.org/ 10.1016/j.dsr.2017.07.003

Medialdea T, Vegas R, Somoza L, Vázquez JT, Maldonado A, Díazdel-Río V, Maestro A, Córdoba D, Fernández-Puga MC (2004) Structure and evolution of the "olistostrome" complex of the Gibraltar Arc in the Gulf of Cádiz (eastern Central Atlantic): evidence from two long seismic cross-sections. Mar Geol 209:173198. https://doi.org/10.1016/j.margeo.2004.05.029

Meijer PTh, Krijgsman W (2005) A quantitative analysis of the desiccation and re-filling of the Mediterranean during the Messinian Salinity Crisis. Earth Planet Sci Lett 240:510-520. https://doi.org/ 10.1016/j.eps1.2005.09.029

Meilijson A, Steinberg J, Hilgen FJ, Bialik OM, Waldmann ND, Makovsky Y (2018) Deep-basin evidence resolves a 50-year-old debate and demonstrates synchronous onset of Messinian evaporite deposition in a non-desiccated Mediterranean. Geology 46:243-246. https://doi.org/10.1130/G39868.1

Millot C, Candela J, Fuda J-L, Tber Y (2006) Large warming and salinification of the Mediterranean outflow due to changes in its composition. Deep Sea Res Part I 53:656-666. https://doi.org/10. 1016/j.dsr.2005.12.017

O'Neill-Baringer M, Price JF (1997) Mixing and spreading of the Mediterranean outflow. J Phys Oceanogr 27:1654-1677. https:// doi.org/10.1175/1520-0485(1997)027\%3c1654:MASOTM\% 3e2.0.CO;2

O'Neill-Baringer M, Price JF (1999) A review of the physical oceanography of the Mediterranean outflow. Mar Geol 155:63-82. https:// doi.org/10.1016/S0025-3227(98)00141-8

Ozgokmen TM, Chassignet EP, Rooth CGH (2001) On the connection between the Mediterranean Outflow and the Azores current. J Phys Oceanogr 31:461-480. https://doi.org/10.1175/15200485(2001)031\%3c0461:OTCBTM\%3e2.0.CO;2

Pérez-Asensio JN, Aguirre J, Schmiedl G, Civis J (2012) Impact of restriction of the Atlantic-Mediterranean gateway on the Mediterranean Outflow Water and eastern Atlantic circulation during the Messinian. Paleoceanography 27:PA3222. https://doi.org/10. 1029/2012PA002309

Pérez-Asensio JN, Larrasoaña JC, Samankassou E, Sierro FJ, García Castellanos D, Jiménez-Moreno G, Salazar Á, Salvany I, Duran JM, Ledesma S, Mata MP, Civis J, Mediavilla C (2018) Magnetobiochronology of Lower Pliocene marine sediments from the lower Guadalquivir basin: insights into the tectonic evolution of the Strait of Gibraltar area. Geol Soc Am Bull 130:1791-1808. https://doi.org/10.1130/B31892.1

Prather BE, Booth JR, Steffens GS, Craig PA (1998) Classification, lithologic calibration, and stratigraphic succession of seismic facies of intraslope basins, deep-water gulf of Mexico. AAPG Bull 82:701-728. https://doi.org/10.1306/1D9BC5D9-172D11D7-8645000102C1865D 
Riaza C, Martínez del Olmo W (1996) Depositional model of the Guadalquivir - Gulf of Cádiz Tertiary basin. In P. F, Friend, \& C. J. Dabrio (Eds), Tertiary basins of Spain: the stratigraphic record of crustal kinematics (pp. 330-338). Cambridge: Cambridge University Press. https://doi.org/10.1017/CBO9780511524851

Rodrigues SM (2017) Seismostratigraphic model of the Sines Contourite Drift (SW Portuguese margin) - depositional evolution, structural control and paleoceanographic implications. (Master's thesis.) Retrieved from Repositório da Universidade de Lisboa. (http://hdl.handle.net/10451/27603). Lisbon: Universidade de Lisboa.

Rogerson M, Bigg GR, Rohling E, Ramirez J (2012a) Vertical density gradient in the eastern North Atlantic during the last 30,000 years. Clim Dyn 39:589-598. https://doi.org/10.1007/ s00382-011-1148-4

Rogerson M, Rohling EJ, Bigg GR, Ramirez J (2012b) Palaeoceanography of the Atlantic-Mediterranean Exchange: overview and first quantitative assessment of climatic forcing. Rev Geophys 50:RG2003. https://doi.org/10.1029/2011RG000376

Rogerson M, Rohling EJ, Weaver PPE, Murray JW (2004) The Azores Front since the Last Glacial Maximum. Earth Planet Sci Lett 222:779-789. https://doi.org/10.1016/j.epsl.2004.03.039

Rogerson M, Rohling EJ, Weaver PPE, Murray JW (2005) Glacial to interglacial changes in the settling depth of the Mediterranean outflow plume. Paleoceanography 20:PA3007. https://doi.org/10. 1029/2004PA001106

Roque C (2007) Tectonostratigrafia Do Cenozóico Das Margens Continentais Sul E Sudoeste Portuguesas: Um Modelo De Correlação Sismostratigráfica. (Doctoral dissertation.) Retrieved from Repositório da Universidade de Lisboa. (http://hdl.handle.net/ 10451/1521). Lisbon: Universidade de Lisboa.

Roveri M, Flecker R, Krijgsman W, Lofi J, Lugli S, Manzi V, Sierro FJ, Bertini A, Camerlenghi A, De Lange G, Govers R, Hilgen FJ, Hübscher C, Meijer PTh, Stoica M (2014) The Messinian salinity crisis: past and future of a great challenge for marine sciences. Mar Geol 352:25-58. https://doi.org/10.1016/j.margeo.2014.02. 002

Sánchez-Leal RF, Bellanco MJ, Fernández-Salas LM, García-Lafuente J, Gasser-Rubinat M, González-Pola C, Hernández-Molina FJ, Pelegrí JL, Peliz A, Relvas P, Roque D, Ruiz-Villarreal M, Sammartino S, Sánchez-Garrido JC (2017) The Mediterranean overflow in the Gulf of Cadiz: a rugged journey. Sci Adv 3:eaao0609. https://doi.org/10.1126/sciadv.aao0609

Scheel DM, Slater GJ, Kolokotronis S-O, Potter CW, Rotstein DS, Tsangaras K, Greenwood AD, Helgen KM (2014) Biogeography and taxonomy of extinct and endangered monk seals illuminated by ancient DNA and skull morphology. ZooKeys 409:1-33. https://doi.org/10.3897/zookeys.409.6244

Schönfeld J, Zahn R, Abreu L (2003) Surface and deep water response to rapid climate changes at the Western Iberian Margin. Glob Planet Change 36:237-264. https://doi.org/10.1016/S09218181(02)00197-2

Scotese CR (2014) Atlas of Neogene Paleogeographic maps (Mollweide Projection) PALEOMAP Atlas for ArcGIS, Volume 1, The Cenozoic (Maps No. 1-7). Evanston, IL: PALEOMAP Project https://doi.org/10.13140/2.1.4151.3922

Selli R (1960) Il Messiniano Mayer-Eymar 1867. Proposta di un neostratotipo. Giornale di Geologia 28:1-33

Siddall M, Pratt LJ, Helfrich KR, Giosan L (2004) Testing the physical oceanographic implications of the suggested sudden Black Sea infill 8400 years ago. Paleoceanography 19:PA1024. https://doi. org/10.1029/2003PA000903
Sierro FJ, Flores JA, Francés G, Vazquez A, Utrilla R, Zamarreño I, Erlenkeuser H, Barcena MA (2003) Orbitally-controlled oscillations in planktic communities and cyclic changes in western Mediterranean hydrography during the Messinian. Palaeogeogr Palaeoclimatol Palaeoecol 190:289-316. https://doi.org/10.1016/ S0031-0182(02)00611-9

Sierro FJ, González Delgado JA, Dabrio CJ, Flores JA, Civis J (1996) Late Neogene depositional sequences in the foreland basin of Guadalquivir (SW Spain). In P. F. Friend \& C. J. Dabrio (Eds), Tertiary basins of Spain: The Stratigraphic Record of Crustal Kinematics (pp.339-345). Cambridge: Cambridge University Press. https://doi.org/10.1017/CBO9780511524851.048

Sierro FJ, Hilgen FJ, Krijgsman W, Flores JA (2001) The Abad composite (SE Spain): a Mediterranean and global reference section for the Messinian. Palaeogeogr Palaeoclimatol Palaeoecol 168:141-169. https://doi.org/10.1016/S0031-0182(00)00253-4

Sierro FJ, Hodell DA, Andersen N, Azibeiro LA, Jimenez-Espejo FJ, Bahr A, Flores JA, Ausin B, Rogerson M, Lozano-Luz R, Lebreiro SM, Hernandez-Molina FJ (2020) Mediterranean overflow over the Last $250 \mathrm{kyr}$ : freshwater forcing from the tropics to the ice sheets. Paleoceanography Paleoclimatol 35. https://doi.org/10. 1029/2020PA003931

Sierro FJ, Ledesma S, Flores JA (2008) Astrobiochronology of Late Neogene deposits near the Strait of Gibraltar (SW Spain): implications for the tectonic control of the Messinian Salinity Crisis. In: Briand F (ed) The Messinian salinity crisis from mega-deposits to microbiology - A consensus report: $\mathrm{N}^{\circ} 33$ in CIESM Workshop Monographs. CIESM Publisher, Monaco, pp 45-48

Sierro FJ, Ledesma S, Flores JA, Torrescusa S, Martínez del Olmo W (2000) Sonic and gamma ray astrochronology: cycle to cycle calibration of Atlantic climatic records to Mediterranean sapropels and astronomical oscillations. Geology 28:695-698. https://doi. org/10.1130/0091-7613(2000)28\%3c695:SAGACT\%3e2.0.CO;2

Simon D, Meijer PTh (2015) Dimensions of the Atlantic-Mediterranean connection that caused the Messinian Salinity Crisis. Mar Geol 364:53-64. https://doi.org/10.1016/j.margeo.2015.02.004

Simon D, Meijer PTh (2017) Salinity stratification of the Mediterranean Sea during the Messinian crisis: a first model analysis. Earth Planet Sci Lett 479:366-376. https://doi.org/10.1016/j.eps1. 2017.09.045

Steinthorsdottir M, Coxal HK, De Boer AM, Huber M, Barbolini N, Bradshaw CD, Burls NJ, Feakins SJ, Gasson E, Henderiks J, Holbourn A, Kiel S, Kohn MJ, Knorr G, Kürschner WM, Lear CH, Liebrand D, Lunt DJ, Mörs T, Pearson PN, Pound MJ, Stoll H, Strömberg CAE (2020) The Miocene: the future of the past. Paleoceanogr Paleoclimatol, e2020PA004037.

Straume EO, Gaina C, Medvedev S, Nisancioglu KH (2020) Global Cenozoic Paleobathymetry with a focus on the Northern Hemisphere Oceanic Gateways. Gondwana Res 86:126-143. https:// doi.org/10.1016/j.gr.2020.05.011

van der Laan E, Gaboardi S, Hilgen FJ, Lourens LJ (2005) Regional climate and glacial control on high-resolution oxygen isotope records from Ain El Beida (latest Miocene, NW Morocco): a cyclostratigraphic analysis in the depth and time domain. Paleoceanography 20:PA1001. https://doi.org/10.1029/2003PA000995

van der Laan E, Snel E, de Kaenel E, Hilgen FJ, Krijgsman W (2006) No major deglaciation across the Miocene-Pliocene boundary: integrated stratigraphy and astronomical tuning of the Loulja sections (Bou Regreg area, NW Morocco). Paleoceanography 21:1-27. https://doi.org/10.1029/2005PA001193

van der Schee M, Sierro F, Jimenez-Espejo F, Hernández-Molina F, Flecker R, Flores J, Acton G, Gutjahr M, Grunert P, GarcíaGallardo A, Andersen N (2016) Evidence of early bottom water 
current flow after the Messinian salinity crisis in the Gulf of Cádiz. Mar Geol 380:315-329. https://doi.org/10.1016/j.margeo. 2016.04.005

Wüst G (1961) On the vertical circulation of the Mediterranean Sea. J Geophys Res 66:3261-3271. https://doi.org/10.1029/JZ066i010p 03261

Wynn RB, Cronin BT, Peakall J (2007) Sinuous deep-water channels: genesis, geometry and architecture. Mar Pet Geol 24:341-387. https://doi.org/10.1016/j.marpetgeo.2007.06.001

Yoshimura T, Kuroda J, Lugli S, Tamenori Y, Ogawa NO, JiménezEspejo FJ, Isaji Y, Roveri M, Manzi V, Kawahata H (2016) An
X-ray spectroscopic perspective on Messinian evaporite from Sicily: sedimentary fabrics, element distributions, and chemical environments of S and Mg. Geochem Geophys Geosyst 17:1383-1400

Zickfeld K, Eby M, Weaver AJ (2008) Carbon-cycle feedbacks of changes in the Atlantic meridional overturning circulation under future atmospheric $\mathrm{CO}_{2}$. Glob Biogeochem Cycles 22:GB3024. https://doi.org/10.1029/2007GB003118

Publisher's Note Springer Nature remains neutral with regard to jurisdictional claims in published maps and institutional affiliations. 